\title{
Combinatory effects of cereulide and deoxynivalenol on in vitro cell viability and inflammation of human Caco-2 cells
}

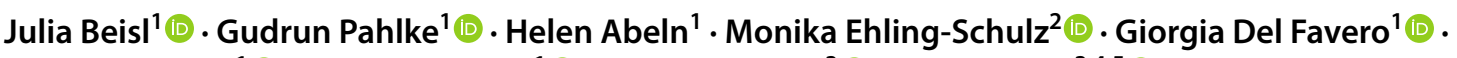

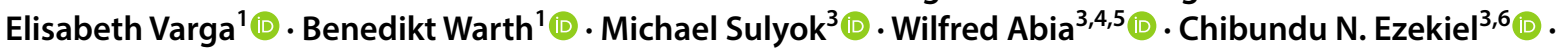 \\ Doris Marko' ${ }^{1}$
}

Received: 25 September 2019 / Accepted: 3 February 2020 / Published online: 17 February 2020

(c) The Author(s) 2020

\begin{abstract}
Deoxynivalenol (DON), one of the most abundant mycotoxins in cereal products, was recently detected with other mycotoxins and the emetic bacterial toxin cereulide (CER) in maize porridge. Within a cereal-based diet, co-exposure to these toxins is likely, hence raising the question of combinatory toxicological effects. While the toxicological evaluation of DON has quite progressed, consequences of chronic, low-dose CER exposure are still insufficiently explored. Information about the combinatory toxicological effects of these toxins is lacking. In the present study, we investigated how CER $(0.1-100 \mathrm{ng} / \mathrm{mL})$ and DON $(0.01-10 \mu \mathrm{g} / \mathrm{mL})$ alone and in a constant ratio of 1:100 (CER:DON) affect the cytotoxicity and immune response of differentiated human intestinal Caco-2 cells. While DON alone reduced cell viability only in the highest concentration $(10 \mu \mathrm{g} / \mathrm{mL})$, CER caused severe cytotoxicity upon prolonged incubation (starting from $10 \mathrm{ng} / \mathrm{mL}$ after $24 \mathrm{~h}$ and $48 \mathrm{~h}, 2.5 \mathrm{ng} /$ $\mathrm{mL}$ and higher after $72 \mathrm{~h}$ ). After $72 \mathrm{~h}$, synergistic effects were observed at $2.5 \mathrm{ng} / \mathrm{mL}$ CER and $0.25 \mu \mathrm{g} / \mathrm{mL}$ DON. Different endpoints of inflammation were investigated in interleukin- $1 \beta$-stimulated Caco- 2 cells. Notably, DON-induced interleukin-8 transcription and secretion were diminished by the presence of 10 and $25 \mathrm{ng} / \mathrm{mL}$ CER after short-term $(5 \mathrm{~h})$ incubation, indicating immunosuppressive properties. We hypothesise that habitual consumption of cereal-based foods co-contaminated with CER and DON may cause synergistic cytotoxic effects and an altered immune response in the human intestine. Therefore, further research concerning effects of co-occurring bacterial toxins and mycotoxins on the impairment of intestinal barrier integrity, intestinal inflammation and the promotion of malnutrition is needed.
\end{abstract}

Keywords Bacillus cereus $\cdot$ Bacterial toxin $\cdot$ Child health $\cdot$ Mycotoxin $\cdot$ Immunomodulation · Food contaminant

Electronic supplementary material The online version of this article (https://doi.org/10.1007/s00204-020-02658-w) contains supplementary material, which is available to authorized users.

Doris Marko

doris.marko@univie.ac.at

1 Department of Food Chemistry and Toxicology, University of Vienna, Währinger Straße 38, 1090 Vienna, Austria

2 Institute of Microbiology, University of Veterinary Medicine, Veterinärplatz 1, 1210 Vienna, Austria

3 Institute of Bioanalytics and Agro-Metabolomics, Department of Agrobiotechnology (IFA-Tulln), University of Natural Resources and Life Sciences, Vienna (BOKU), Konrad Lorenz Str. 20, 3430 Tulln, Austria

\section{Introduction}

The co-occurrence of several mycotoxins and bacterial toxins was recently reported in homemade Cameroonian maize fufu, a maize porridge dish frequently consumed in West and Central Africa (Abia et al. 2017). Among others, cereulide (CER; Fig. 1a), a bacterial toxin produced by some

4 Institute for Global Food Security, Advanced ASSET Centre, School of Biological Sciences, Queen's University Belfast, Belfast, Northern Ireland, UK

5 Laboratory of Pharmacology and Toxicology, Department of Biochemistry, Faculty of Science, University of Yaounde I, P.O. Box 812, Yaounde, Cameroon

6 Department of Microbiology, Babcock University, Ilishan Remo, Ogun State, Nigeria 
(a)

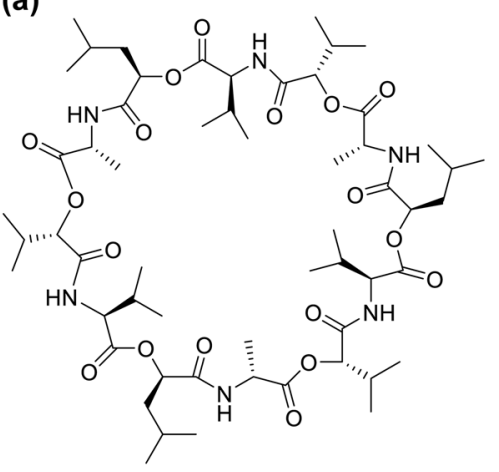

(b)

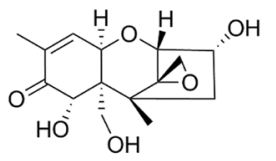

Fig. 1 Chemical structures of cereulide (a) and deoxynivalenol (b)

Bacillus cereus strains with specific genotypic characteristics (Ehling-Schulz et al. 2005) as well as deoxynivalenol (DON; Fig. 1b), a mycotoxin produced by Fusarium species, were detected in all analysed food samples $(n=50)$ (Abia et al. 2017). As Cameroon is a country with a high stunting prevalence of $32 \%$ of children under the age of 5 (European Commission 2018), effects of toxins on promoting factors of stunting are attracting notice. Causes of childhood stunting are multifactorial and include, for example, high mycotoxin exposure, diarrhoeal diseases and intestinal inflammation (Stewart et al. 2013). An association between poor child growth and impaired intestinal integrity as well as inflammatory stimulation was already suggested by Campbell et al. (2003). Furthermore, insufficient nutrient absorption and growth retardation cannot be excluded to occur due to DON exposure (Smith et al. 2012). Both toxins, CER and DON, cause emesis, whereas the induction of intestinal lesions (Pinton et al. 2009) and alterations of the immune response (Maresca et al. 2008) have been additionally reported for DON.

DON is also called "vomitoxin" due to its characteristic symptom of acute intoxication, but also causes symptoms such as nausea, diarrhoea, growth retardation and immune dysregulation (Ueno 1977). Inhibition of protein biosynthesis is considered the main mechanism of action of DON (Pinton and Oswald 2014). Mishra et al. (2019) recently reviewed the worldwide occurrence of DON in foodstuffs and concluded that DON was present in a wide concentration range in grains like wheat, maize or oats and cereal-based products as well as infant food. Consequently, humans are generally exposed to at least low doses of this toxin through their diet, with the gastrointestinal tract being first affected by foodborne toxins. In the human intestinal adenocarcinoma cell line Caco-2, DON caused a reduction of cell viability in undifferentiated cells at concentrations of 1-30 $\mu \mathrm{M}$ (Cano-Sancho et al. 2015; Vejdovszky et al. 2016). However, in a differentiated state, cells seemed to be less sensitive to DON, as no cytotoxicity was reported after

$24 \mathrm{~h}$ for concentrations up to $10 \mu \mathrm{M}$. (Bony et al. 2006; Van De Walle et al. 2010a). Furthermore, DON decreased the transepithelial electrical resistance (TEER) in differentiated Caco- 2 cells, increased paracellular permeability and altered some tight junction proteins (Ling et al. 2016; Pinton et al. 2009), indicating an impairment of intestinal integrity. In differentiated Caco- 2 cells, DON was described to modify the immune response leading to elevated interleukin-8 (IL-8) secretion (Maresca et al. 2008) and increased activation of the NF-kB pathway (Van De Walle et al. 2008). Additionally, DON induced the gene expression of the pro-inflammatory cytokines IL-8, tumour necrosis factor- $\alpha$ (TNF- $\alpha$ ), IL- $1 \alpha$ and IL- $1 \beta$ in IPEC- 1 intestinal porcine epithelial cells (Cano et al. 2013).

The cyclic dodecadepsipeptide ([D- $O$-Leu-D-Ala-L- $O$ Val-L-Val $]_{3}$ ) toxin CER is produced by the non-ribosomal peptide synthase cesNRPS (Ehling-Schulz et al. 2006) and is highly heat and $\mathrm{pH}$ resistant (Rajkovic et al. 2008). Once it is pre-formed in food, it cannot be removed by normal food hygienic measures (Rouzeau-Szynalski et al. 2020). The main symptoms of acute CER poisoning include nausea and emesis (Ehling-Schulz et al. 2004, 2019; Schoeni and Wong 2005) with an estimated toxic dose of $8 \mu \mathrm{g} / \mathrm{kg}$ bodyweight (Jaaskelainen et al. 2003). Furthermore, some fatal cases of CER intoxication are known that led to adverse effects, such as liver failure due to micro-vesicular steatosis and impaired $\beta$-oxidation in liver mitochondria (Mahler et al. 1997) or necrosis of colon mucosa (Naranjo et al. 2011). Furthermore, cytotoxic effects of CER have been described in undifferentiated Caco-2 monolayers (Jaaskelainen et al. 2003) and fully differentiated Caco-2 cells (Rajkovic et al. 2014), at concentrations of $2 \mathrm{ng} / \mathrm{mL}$ and $0.125 \mathrm{ng} / \mathrm{mL}$ CER, respectively. With respect to modulation of the immune response, the effect of CER on natural killer (NK) cells has been investigated by Paananen et al. (2002). They observed induction of apoptosis and inhibition of interferon- $\gamma$ (INF- $\gamma$ ) production. Furthermore, the effects of CER on mitochondria are quite pronounced and include swelling and disruption of the inner membrane (Mikkola et al. 1999; Vangoitsenhoven et al. 2014). The impact on mitochondria is suggested to arise from potassium leakage due to the ionophoretic properties of CER (Mikkola et al. 1999).

The toxic effects of many single compounds have been extensively studied, hence, several mycotoxins such as aflatoxin $\mathrm{B}_{1}$, fumonisins and DON have been discussed in the context of reduced weight gain and growth (Smith et al. 2012). On the other hand, information on the consequences of chronic low-dose exposure to CER is still lacking. In recent years, combinatory effects of numerous substances such as mycotoxin mixtures (Vejdovszky et al. 2016) or combinations of mycotoxins with polyphenols (Aichinger et al. 2017, 2018a; Cano-Sancho et al. 2015) are attracting attention due to their co-occurrence 
or simultaneous ingestion. However, data on many other mycotoxins or bacterial toxins as well as data on the combinations of CER and DON or any other mycotoxin are still lacking. Furthermore, the impact of chronic exposure to sub-emetic doses of CER and DON on the intestinal epithelium is largely unknown. Therefore, this study focused on the effects of CER and DON alone and in combinatory mixtures on cell viability and alterations of the inflammatory response of differentiated intestinal Caco- 2 cells in physiologically relevant concentrations.

\section{Materials and methods}

\section{Chemicals and consumables}

DON was purchased from Romer Labs (Tulln, Austria); CER was purified according to Bauer et al. (2018). Neutral Red dye and lipopolysaccharide (LPS) were obtained from Sigma-Aldrich (Taufkirchen, Germany) and alamarBlue ${ }^{\mathrm{TM}}$ from Invitrogen (Carlsbad, USA). Cell culture media, supplements and Dulbecco's phosphate-buffered saline (DPBS) were purchased from Gibco ${ }^{\circledR}$ Life Technologies (Karlsruhe, Germany). Heat-killed Listeria monocytogenes (HKLM) and recombinant human interleukin-1 $\beta$ (IL-1 $\beta$ ) were obtained from InvivoGen (Toulouse, France). Ethanol (absolute) and glacial acetic acid were purchased from Fisher Chemical (Loughborough, UK).

\section{Caco-2 (C2BBe1) cells}

The Caco-2 clone C2BBe1 (ATCC-CRL-2102), a cell line originally established from a colorectal adenocarcinoma, able to differentiate into a polarised monolayer with an apical brush boarder, was acquired from the American Type Culture Collection (ATCC; Manassas, VA, USA). Cells were cultivated under humidified conditions $\left(37^{\circ} \mathrm{C}\right.$, $5 \% \mathrm{CO}_{2}, 95 \%$ humidity) in Dulbecco's Modified Eagle Medium (DMEM) supplemented with $10 \%(v / v)$ fetal calf serum (FCS), $1 \%(v / v)$ penicillin/streptomycin $(\mathrm{P} / \mathrm{S}$; $100 \mathrm{U} / \mathrm{mL} / 100 \mu \mathrm{g} / \mathrm{mL}), 1 \%(v / v)$ potassium pyruvate and $0.01 \mathrm{mg} / \mathrm{mL}$ transferrin. Cells were sub-cultivated twice a week at a confluency of $80 \%$, seeded for experiments in 96-well or 24-well tissue culture plates (Cell+, Sarstedt, Nümbrecht, Germany) at a density of 85,000 cells $/ \mathrm{cm}^{2}$ and allowed to grow for 7 days prior to experiments to receive a partially differentiated, tight monolayer as previously reported by Schmutz et al. (2019). The used passage numbers were below 40. Medium was renewed every 2-3 days. Cells were routinely checked for mycoplasma contamination.

\section{THP1-Lucia ${ }^{\mathrm{TM}}$ NF-KB cells}

NF- $\kappa B$ Lucia ${ }^{\mathrm{TM}}$ Reporter Monocytes, originating from THP-1 cells that were integrated with a stable NF- $\mathrm{KB}$ inducible Lucia ${ }^{\mathrm{TM}}$ reporter construct, were purchased from InvivoGen (Toulouse, France). Cells were cultivated following the provider's instructions. (InvivoGen 2017) Briefly, cells were cultivated in Roswell Park Memorial Institute (RPMI)-1640 medium containing $2 \mathrm{mM}$ L-glutamine and $25 \mathrm{mM}$ HEPES supplemented with $10 \%(v / v)$ FCS and $1 \%(v / v) \mathrm{P} / \mathrm{S}(100 \mathrm{U} /$ $\mathrm{mL} / 100 \mu \mathrm{g} / \mathrm{mL}$ ). In order not to exceed a maximum cell number of $2 \times 10^{6}$ cells $/ \mathrm{mL}$, cells were sub-cultivated twice a week by transferring $375,000-450,000$ cells into a new flask. The selective antibiotic Zeocin ${ }^{\mathrm{TM}}$ and Normocin ${ }^{\mathrm{TM}}$ were added to the culture every other passage to maintain selection pressure and prevent bacterial contamination, respectively. Cells were routinely checked for mycoplasma contamination.

\section{Incubation conditions and justification of exposure}

DON stock solutions were prepared in water, CER stock solutions in DMSO. Cells were treated with $0-100 \mathrm{ng} / \mathrm{mL}$ CER and/or $0-10 \mu \mathrm{g} / \mathrm{mL}$ DON with a final solvent concentration of $1 \%$ DMSO and $1 \% \mathrm{H}_{2} \mathrm{O}$ in all incubation solutions. In all experiments, medium containing $1 \%$ DMSO and $1 \%$ $\mathrm{H}_{2} \mathrm{O}$ was used as solvent control. To mimic inflammatory conditions, cells were stimulated with $25 \mathrm{ng} / \mathrm{mL} \mathrm{IL}-1 \beta$ as previously described for Caco-2 monolayers (Van De Walle et al. 2008, 2010b;). Exposure levels are based on occurrence data (Abia et al. 2017; Mishra et al. 2019; Schothorst and van Egmond 2004) and are described in detail in the discussion section. All experiments were performed with at least three biological replicates.

\section{Cell viability: neutral red (NR) assay}

As a measure for cell viability, the neutral red assay was performed as previously described (Repetto et al. 2008). Briefly, Caco- 2 cells were seeded in 96-well plates, grown for 7 days, treated with the respective incubation media in triplicates and incubated for $5 \mathrm{~h}$ (with or without IL- $1 \beta$ stimulus for the last $3 \mathrm{~h}$ ), $24 \mathrm{~h}, 48 \mathrm{~h}$ or $72 \mathrm{~h}$. The NR staining medium was prepared by diluting a $40 \mathrm{mg} / \mathrm{mL}$ NR solution 1:100 with cell culture medium. After incubating the staining solution over night at $37{ }^{\circ} \mathrm{C}$, it was centrifuged for $10 \mathrm{~min}$ at $600 \times g$ to remove precipitated dye. At the end of the cell incubation, the medium was replaced by $100 \mu \mathrm{L}$ of $\mathrm{NR}$ staining solution and incubated for $3 \mathrm{~h}$ prior to washing with $150 \mu \mathrm{L}$ pre-warmed DPBS. Subsequently, the cells were treated with $150 \mu \mathrm{L}$ of freshly prepared destain solution (50:50:1 ethanol absolute, $\mathrm{dH}_{2} \mathrm{O}$, glacial acetic acid) and shaken for $10 \mathrm{~min}$ at $500 \mathrm{rpm}$. Subsequently, $130 \mu \mathrm{L}$ of the 
destain solution was transferred to a fresh 96-well plate to measure absorbance at $540 \mathrm{~nm}$ with the Cytation 3 imaging reader (BioTek, USA). Results are related to the respective solvent control (test/control [\%]).

\section{NF-kB reporter gene assay}

To monitor the potential induction or suppression of the $\mathrm{NF}-\kappa \mathrm{B}$ signal transduction pathway by the test substances, the NF- $\kappa B$ reporter gene assay was performed with THP1Lucia $^{\mathrm{TM}} \mathrm{NF}-\mathrm{\kappa B}$ cells following the provider's suggestion (InvivoGen 2017) with some modifications. Through expression of the integrated Luciferase reporter construct, modifications in the activation of the NF- $\mathrm{KB}$ pathway can be monitored. After sub-cultivating the cells, the remaining cell suspension was centrifuged $(4 \mathrm{~min}, 200 \times \mathrm{g})$, the supernatant was discarded and the cells were resuspended in fresh medium. Subsequently, 100,000 cells/100 $\mu \mathrm{L} /$ well were seeded into a 96-well plate and incubated with the respective substances in triplicates for $20 \mathrm{~h}$. After $2 \mathrm{~h}$ of incubation, cells were stimulated with $1 \mu \mathrm{L}$ of a $1 \mu \mathrm{g} / \mathrm{mL}$ LPS solution to mimic inflammatory conditions. A solvent control incubated with LPS for $18 \mathrm{~h}$ served as the positive control. Additionally, another positive control containing $200 \times 10^{6}$ heat-killed Listeria monocytogenes (HKLM) per $\mu \mathrm{L}$ was measured. At the end of the incubation period, the plate was centrifuged ( $2 \mathrm{~min}, 200 \times \mathrm{g}$ ) and $10 \mu \mathrm{L}$ of the supernatant was transferred into an opaque 96-well plate to determine luciferase activity. Luminescence was detected with the Cytation3 imaging reader (BioTek, USA) after the injection of $50 \mu \mathrm{L}$ of QUANTI-Luc ${ }^{\mathrm{TM}}$.

\section{alamarBlue $^{\mathrm{Tm}}$ cell viability assay}

To ensure that effects on the NF- $\kappa \mathrm{B}$ pathway are not an artefact because of cytotoxicity, the alamarBlue ${ }^{\mathrm{TM}}$ viability assay was performed directly after incubation of the THP1Lucia $^{\mathrm{TM}} \mathrm{NF}-\kappa \mathrm{B}$ cells for the reporter gene assay. Briefly, $10 \mu \mathrm{L}$ of alamarBlue ${ }^{\mathrm{TM}}$ was added to the cell suspension and incubated at $37^{\circ} \mathrm{C}$ for $2 \mathrm{~h}$. The plate was centrifuged as described above, $50 \mu \mathrm{L} /$ well was transferred into a black 96-well plate and fluorescence was measured with a Cytation3 imaging reader (BioTek, USA) using an excitation wavelength of $530 \mathrm{~nm}$ and an emission wavelength of $560 \mathrm{~nm}$.

\section{Gene transcription analysis (quantitative real-time PCR)}

The impact of DON, CER or a combination of both on the transcript level of selected cytokines was assessed using quantitative real-time PCR (qPCR). After the respective incubation period of $5 \mathrm{~h}(2 \mathrm{~h}$ pre-incubation with CER,
DON or mixture and $3 \mathrm{~h}$ co-incubation with $25 \mathrm{ng} / \mathrm{mL}$ of IL-1 $\beta$ ) total RNA was extracted with the Maxwell ${ }^{\circledR} 16$ LEV simplyRNA Cells Kit (Promega, Madison, WI, USA) and reverse transcribed into complementary DNA (cDNA; QuantiTect ${ }^{\circledR}$ Reverse Transcription Kit, Qiagen, Hilden, Germany) following the suppliers' protocols. Amplification of gene-specific DNA was performed in the presence of QuantiTect ${ }^{\circledR}$ SYBR $^{\circledR}$ Green Master Mix (Qiagen) and sequence-specific primers (QuantiTect ${ }^{\circledR}$ Primer Assays, Qiagen) with the StepOnePlus ${ }^{\mathrm{TM}}$ System (Applied Biosystems). The following primer assays were used: tubulin, beta polypeptide (TUBB; Hs_TUBB_1_SG, QT00089775), hypoxanthine phosphoribosyltransferase 1 (HPRT1; Hs_HPRT1_1_ SG, QT00059066), interleukin-8 (IL-8; Hs_CXCL8_1_SG, QT00000322), interleukin-1 $\beta$ (IL-1 $\beta$; Hs_IL1B_1_SG, QT00021385), and tumour necrosis factor- $\alpha$ (TNF- $\alpha$; Hs TNF_1_SG, QT00029162). A universal PCR protocol was used for amplification (enzyme activation: $15 \mathrm{~min}$ at $95^{\circ} \mathrm{C}$; 45 cycles of $15 \mathrm{~s}$ at $94{ }^{\circ} \mathrm{C}, 30 \mathrm{~s}$ at $55^{\circ} \mathrm{C}$ and $30 \mathrm{~s}$ at $72{ }^{\circ} \mathrm{C}$, followed by melting curve analysis: $15 \mathrm{~s}$ at $95^{\circ} \mathrm{C}, 1 \mathrm{~min}$ at $60{ }^{\circ} \mathrm{C}$, in $0.5{ }^{\circ} \mathrm{C}$ steps to $94{ }^{\circ} \mathrm{C}$ for $15 \mathrm{~s}$ ) and analysed with the StepOnePlus ${ }^{\circledR}$ software v2.1. Data were normalised to the mean of transcript levels of two endogenous control genes, TUBB and HPRT1, and quantified with the $2^{-\Delta \Delta C t}$ method (Livak and Schmittgen 2001), as similar PCR efficiency was ensured according to Schmittgen and Livak (2008). Data are presented as fold-changes in comparison to the IL-1 $\beta$ stimulated control sample, which was set to 1 .

\section{Cytokine secretion: multiplex assay}

Secreted protein concentrations of IL- 8 and TNF- $\alpha$ were assessed in cell culture supernatants with a Human Magnetic Luminex ${ }^{\circledR}$ Assay (R\&D Systems, Inc., USA). The secretion of IL-1 $\beta$ could not be determined due to the stimulation of the cells therewith resulting in an excess amount in the supernatant. Cells were incubated as described for qPCR, though only the most promising concentrations, namely the two with the strongest induction of gene expression, were chosen. The assay was performed according to the manufacturer's recommendation. Briefly, diluted supernatants and standards were incubated with magnetic microparticles coated with analyte-specific antibodies. Consecutively, the particles were incubated with a specific biotinylated antibody cocktail as well as streptavidin-phycoerythrin conjugate. Samples were then analysed in duplicates with the BioRad Bio-Plex ${ }^{\circledR} 200$ System. Concentrations were calculated by applying a five-parameter logistic (5-PL) curve fit with Bio-Plex Manager ${ }^{\mathrm{TM}}$ 6.1. 


\section{Statistical analysis}

Statistical and graphical analyses were performed using OriginPro 2018G. To ensure normal distribution of the data, all datasets were analysed with Shapiro-Wilk normality test. The Nalimov outlier test was applied to eliminate outliers. To assess interactions between the test compounds, a mathematical model, the "Independent Joint Action" by Webb (1963), was used whenever possible as previously published (Aichinger et al. 2016, 2018b). An expected combined effect was calculated with the equation $f_{a b}=f_{a}+f_{b}-f_{a} f_{b}$ and compared to the measured combined effect using two-sample Student's $t$ test. To analyse significant differences between different concentrations of the same substances, one-way ANOVA was performed using Bonferroni post hoc test. To compare two different conditions, e.g. DON with the respective mixture, a two-sample Student's $t$ test was performed. In all statistical analyses, following $p$ values were applied: ${ }^{*} p<0.05 ; * * p<0.01 ; * * * p<0.001$.

\section{Results}

\section{Impairment of cell viability}

To investigate the effects of CER and DON on cell viability and to prevent artefacts in data interpretation, the NR assay measuring the amount of dye bound in the lysosomes of viable cells was performed. After an incubation period of $5 \mathrm{~h}$, DON and CER did not significantly affect the viability of differentiated Caco-2 cells (Fig. 2a).

In contrast, after $24 \mathrm{~h}$ incubation, CER mediated a significant decrease of NR absorbance at $10 \mathrm{ng} / \mathrm{mL}$ and $100 \mathrm{ng} /$ $\mathrm{mL}$ to $81.4 \pm 10.0 \%$ and $77.8 \pm 4.1 \%$, respectively (Fig. $2 b$ ). DON showed a dose-dependent trend resulting in a significant reduction of NR absorbance to $78.9 \pm 3.0 \%$ at the highest dose of $10 \mu \mathrm{g} / \mathrm{mL}$ DON, indicating cytotoxic effects. Comparing the measured combined effects to the calculated combined effect, according to Webb (1963), a significant antagonistic effect is evident at concentrations of $100 \mathrm{ng} /$ $\mathrm{mL} \mathrm{CER}+10 \mu \mathrm{g} / \mathrm{mL}$ DON, meaning that the measured cell viability, namely $82.4 \pm 9.2 \%$, is significantly higher than the mathematically expected viability of $62.3 \pm 6.1 \%$, calculated on the basis of the single compounds.

After $48 \mathrm{~h}$ of incubation, viability of Caco-2 cells was potently decreased by CER starting from $10 \mathrm{ng} / \mathrm{mL}$ (Fig. 2c). In contrast, DON induced only a minor reduction of viability with a maximum of $74.8 \pm 10.0 \%$ at $10 \mu \mathrm{g} / \mathrm{mL}$. The mixture of both toxins reduced cell viability as well, starting at $10 \mathrm{ng} /$ $\mathrm{mL}$ CER $+1 \mu \mathrm{g} / \mathrm{mL}$ DON. Comparison of measured and calculated effects of the toxin combination revealed significant antagonistic effects on cell viability at the lowest concentrations $(0.1 \mathrm{ng} / \mathrm{mL}$ CER $+0.01 \mu \mathrm{g} / \mathrm{mL}$ DON, $1 \mathrm{ng} / \mathrm{mL}$
CER $+0.1 \mu \mathrm{g} / \mathrm{mL}$ DON). Of note, at higher concentrations $(25 \mathrm{ng} / \mathrm{mL}$ CER $+2.5 \mu \mathrm{g} / \mathrm{mL}$ DON$)$, the measured absorbance of only $18.3 \pm 12.5 \%$ in comparison to the solvent control was in clear contrast to the calculated $43.2 \pm 19.5 \%$, suggesting a synergistic effect of the toxin mixture (Fig. 2c). Furthermore, in the other concentrations, no significant differences between the measured and the calculated combined effect became apparent indicating additive effects.

Prolonged incubation (72 h), mimicking chronic exposure, caused even more pronounced reduction of Caco-2 cell viability (Fig. 2d), resulting in a significant decrease for the toxin combination already at $2 \mathrm{ng} / \mathrm{mL}$ CER $+0.2 \mu \mathrm{g} /$ $\mathrm{mL}$ DON. CER as a single substance induced a significant reduction of NR absorbance at $2.5 \mathrm{ng} / \mathrm{mL}(67.1 \pm 17.8 \%)$ and substantially decreased it to $4.5 \pm 3.3 \%$ and $1.2 \pm 1.8 \%$ at concentrations of $3 \mathrm{ng} / \mathrm{mL}$ and $5 \mathrm{ng} / \mathrm{mL}$ CER, respectively. Compared to the other exposure time points, DON again had no significant impact on cell viability in lower concentrations $(0.01-0.5 \mu \mathrm{g} / \mathrm{mL})$. Incubations with more than $5 \mathrm{ng} / \mathrm{mL}$ CER, alone or in combination with DON, led to a complete loss of cell viability. Thus, other concentrations (at sub-emetic doses) than those used for short-time incubation of 5-48 h had to be chosen. The synergistic effect of CER and DON was even more pronounced after $72 \mathrm{~h}$. For example, the measured absorbance of the CER/DON mixture $(2.5 \mathrm{ng} / \mathrm{mL}$ CER $+0.25 \mu \mathrm{g} / \mathrm{mL}$ DON $)$ of $16.9 \pm 21.3 \%$ compared to the solvent control is in pronounced contrast to the calculated value of $66.2 \pm 18.1 \%$ even though this potent synergistic effect vanishes with increased concentrations and thus cell death.

\section{Effects on NF-kB activity}

The question whether and how mixtures of toxins affect the immune response differently than the single toxins was addressed amongst others by investigating the impact on NF- $\kappa \mathrm{B}$ activity as recently reported by Kollarova et al. (2018). A good test model for studies regarding the inducibility of the NF- $\kappa$ B pathway is THP1-Lucia ${ }^{\mathrm{TM}} \mathrm{NF}-\kappa \mathrm{B}$ monocytes (InvivoGen 2017). These cells comprise an inducible NF- $\kappa \mathrm{B}$ promotor leading to the expression of luciferase after activation. To avoid potential artefacts due to cytotoxic effects, the alamarBlue ${ }^{\mathrm{TM}}$ assay was performed with THP1-Lucia ${ }^{\mathrm{TM}} \mathrm{NF}-\kappa \mathrm{B}$ monocytes first. Cell viability was significantly decreased by DON alone in concentrations of $0.5 \mu \mathrm{g} / \mathrm{mL}$ and $1 \mu \mathrm{g} / \mathrm{mL}$ as well as in the respective combinations with $5 \mathrm{ng} / \mathrm{mL}$ and $10 \mathrm{ng} / \mathrm{mL}$ CER (Fig. 3a). The NF-KB pathway was not significantly activated by the test substances even though a dose-dependent trend may be present for DON (Fig. 3b). However, coincubation of CER+DON resulted in a significant suppression of the activation mediated by DON at concentrations of $0.1 \mathrm{ng} / \mathrm{mL}$ CER $+0.01 \mu \mathrm{g} / \mathrm{mL}$ DON. The same trend, 


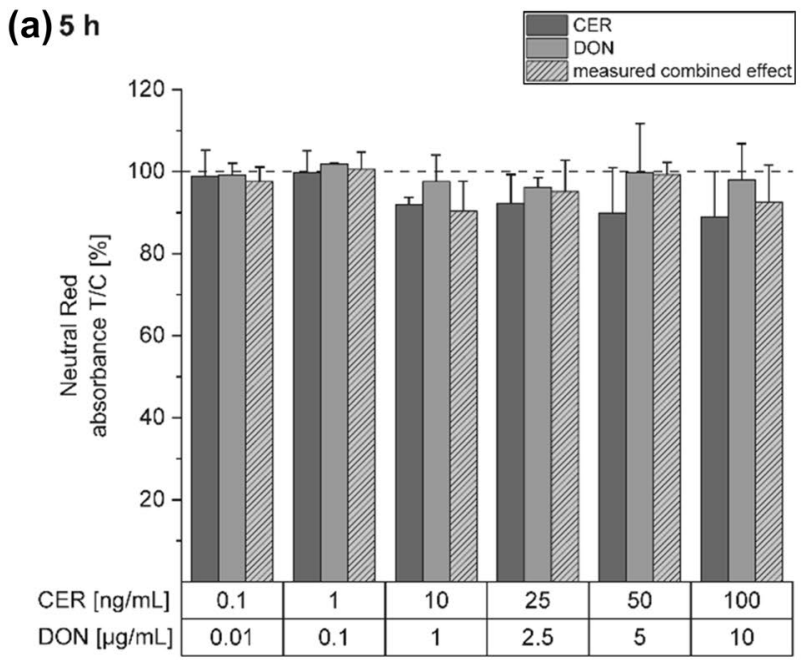

(c) $48 \mathrm{~h}$

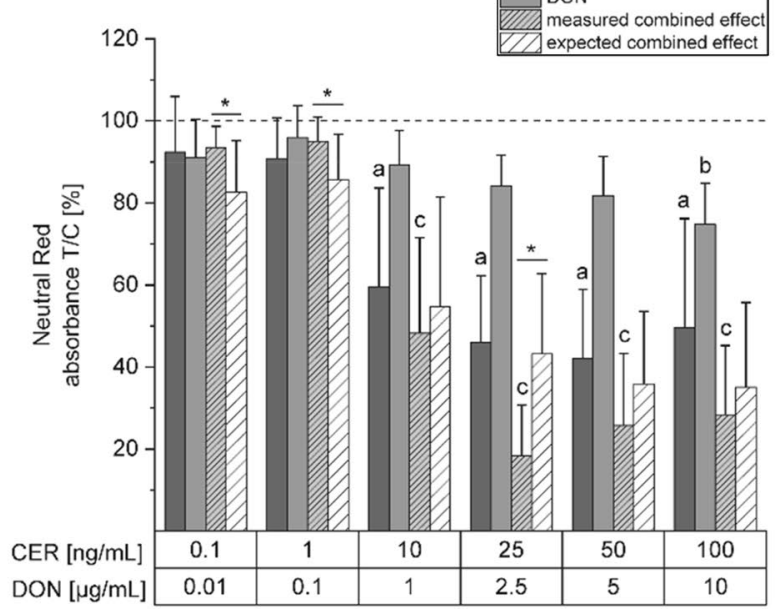

Fig. 2 Cell viability of differentiated Caco-2 cells after incubation with CER (dark grey), DON (grey), a combination of both toxins (light grey, dashed) and a calculated combination (white, dashed) measured by Neutral Red assay after $5 \mathrm{~h} \mathrm{(a),} 24 \mathrm{~h}(\mathbf{b}), 48 \mathrm{~h}(\mathbf{c})$ and $72 \mathrm{~h}$ (d) of incubation. Results are presented as means + standard deviations, normalised to the solvent control (1\% v/v DMSO, $1 \%$ $v / v \mathrm{H}_{2} \mathrm{O}$; dashed line) $(n \geq 4)$. The calculated measured effects were

even though not significant, was observed in other concentrations. Despite commencing cytotoxicity this effect persists at the combination of $10 \mathrm{ng} / \mathrm{mL}$ CER $+1 \mu \mathrm{g} / \mathrm{mL}$ DON.

\section{Modulatory effects on transcript levels of IL-8 (CXCL8), TNF- $\alpha$ (TNF) and IL-1 $\beta$ (IL1B)}

As the NF-kB Reporter Gene Assay is quite unspecific, gene transcription of the pro-inflammatory cytokines IL- 8 , TNF- $\alpha$ and IL-1 $\beta$ was investigated (Fig. 4). Cell viability of IL-1 $\beta$ stimulated cells was monitored with the NR assay (Online Resource 1). CER alone had no measurable effect on CXCL8
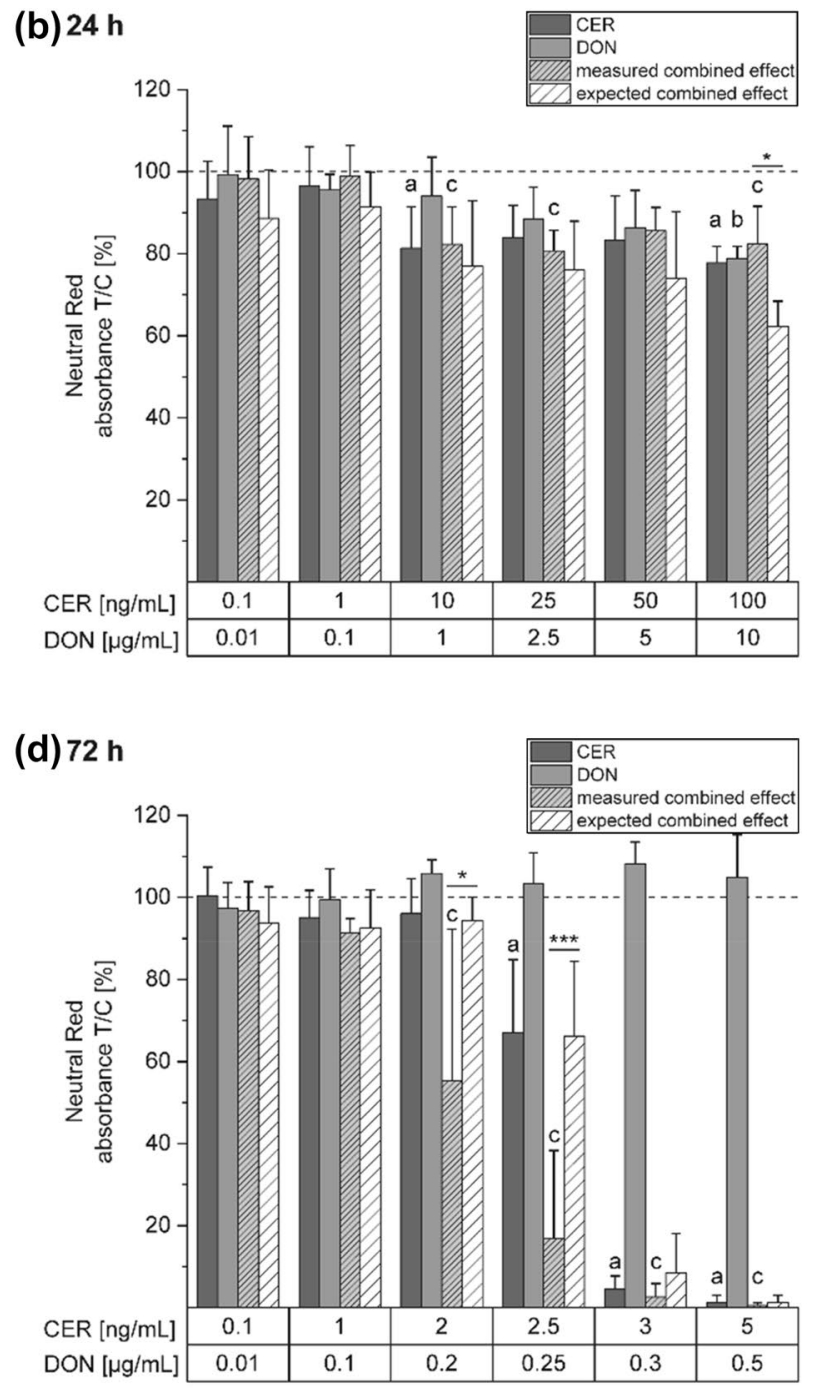

determined by independent joint action (Webb 1963). Significant differences to the respective no-effect concentration were calculated by one-way ANOVA $(p<0.05)$ followed by Bonferroni post hoc test and are indicated as "a" (CER), "b" (DON) and "c" (measured combined effect). Significant differences between the measured and the calculated combined effect were determined by Student's $t$ test and are indicated with "**" $(p<0.05)$ and “****" $(p<0.001)$

transcription, whereas DON led to an increase thereof up to $66.8 \pm 21.7$-fold compared to the IL- $1 \beta$-stimulated control in the highest tested concentration. The toxin combination on the other hand significantly counteracted the effect of DON over the entire concentration range leading to a still upregulated $C X C L 8$ transcription in the combination of 10 and $25 \mathrm{ng} / \mathrm{mL}$ CER with 1 and $2.5 \mu \mathrm{g} / \mathrm{mL}$ DON, respectively. In contrast to $C X C L 8$, mRNA levels of $I L 1 B$ are diminished by incubation with CER to $0.2 \pm 0.03$-fold, while DON induced the gene transcription to $5.4 \pm 2.0$-fold and $4.4 \pm 2.9$-fold at concentrations of $1 \mu \mathrm{g} / \mathrm{mL}$ and $2.5 \mu \mathrm{g} /$ $\mathrm{mL}$ DON. In addition, the combination with DON and CER 


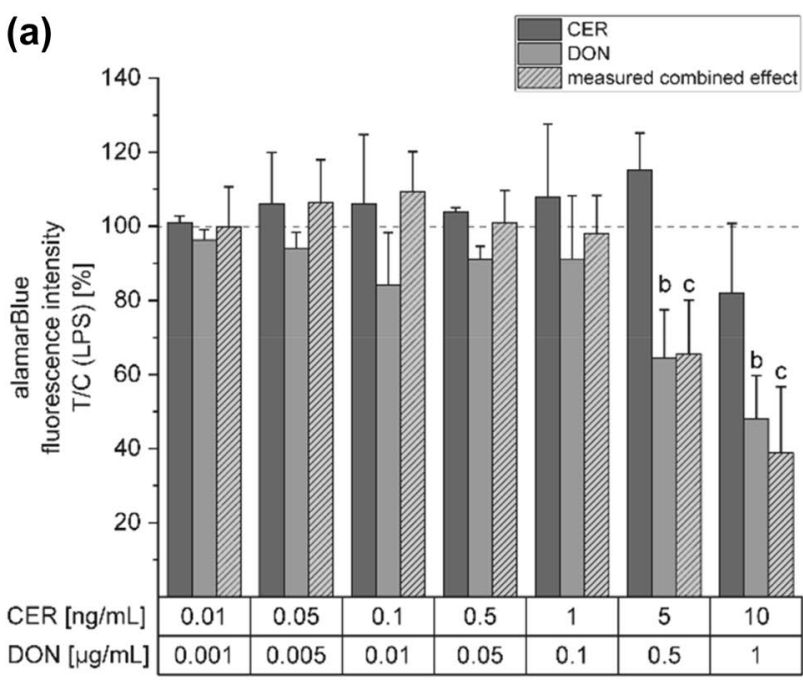

Fig. 3 Cell viability (a) and luciferase activity (b) of LPS stimulated THP1-Lucia ${ }^{\mathrm{TM}} \mathrm{NF}-\kappa \mathrm{B}$ cells. Cells were incubated with CER (dark grey), DON (grey) and a combination of both toxins (light grey, dashed) for $20 \mathrm{~h}$ and stimulated with LPS for the last $18 \mathrm{~h}$. Results are presented as means + standard deviations, normalised to the solvent control (1\% v/v DMSO, $1 \% v / v \mathrm{H}_{2} \mathrm{O}$; dashed line) ( $\left.n \geq 7\right)$. Significant

led to a significant reduction of the amount of mRNA in the highest tested concentration. Concerning TNF, both CER and DON enhanced the transcript levels to $7.5 \pm 5.7$ - and 105.4 \pm 49.5 -fold, respectively. However, in the combination of $10 \mathrm{ng} / \mathrm{mL}$ CER $+1 \mu \mathrm{g} / \mathrm{mL}$ DON, gene transcription was significantly increased to $81.7 \pm 12.7$-fold, an effect that does not persist in higher concentrations. Threshold cycles $\left(C_{\mathrm{t}}\right.$ values) of housekeeping and target cytokine mRNA are displayed in Online Resource 2.

\section{Cytokine secretion}

To study whether the gene transcription levels are reflected in the cytokine secretion of the cells, IL- 8 and TNF- $\alpha$ were analysed in the cell culture supernatants by a multiplex assay. Based on the qPCR results, the concentrations appearing to be the most prominent due to their strongest induction of gene expression were chosen. TNF- $\alpha$ concentrations were too low for valid quantification (data not shown). In the IL-1 $\beta$-stimulated control, $178.3 \pm 14.2 \mathrm{pg} / \mathrm{mL}$ IL- 8 were detected (Fig. 5). $25 \mathrm{ng} / \mathrm{mL}$ CER led to a significant reduction of the IL-8 concentration to $121.7 \pm 11.5 \mathrm{pg} / \mathrm{mL}$ compared to the stimulated samples. Supernatants treated with 1 and $2.5 \mu \mathrm{g} / \mathrm{mL}$ DON on the other hand showed elevated levels of IL-8 up to $711.3 \pm 98.0$ and $389.6 \pm 75.1 \mathrm{pg} / \mathrm{mL}$, respectively. Remarkably, in the combinations of $10 \mathrm{ng} / \mathrm{mL}$ CER $+1 \mu \mathrm{g} / \mathrm{mL}$ DON as well as $25 \mathrm{ng} / \mathrm{mL}$ CER $+2.5 \mu \mathrm{g} /$ $\mathrm{mL}$ DON, IL-8 concentrations in the cell culture supernatants were significantly reduced to $367.5 \pm 144.9$ and $105.7 \pm 14.4 \mathrm{pg} / \mathrm{mL}$ compared to the respective DON

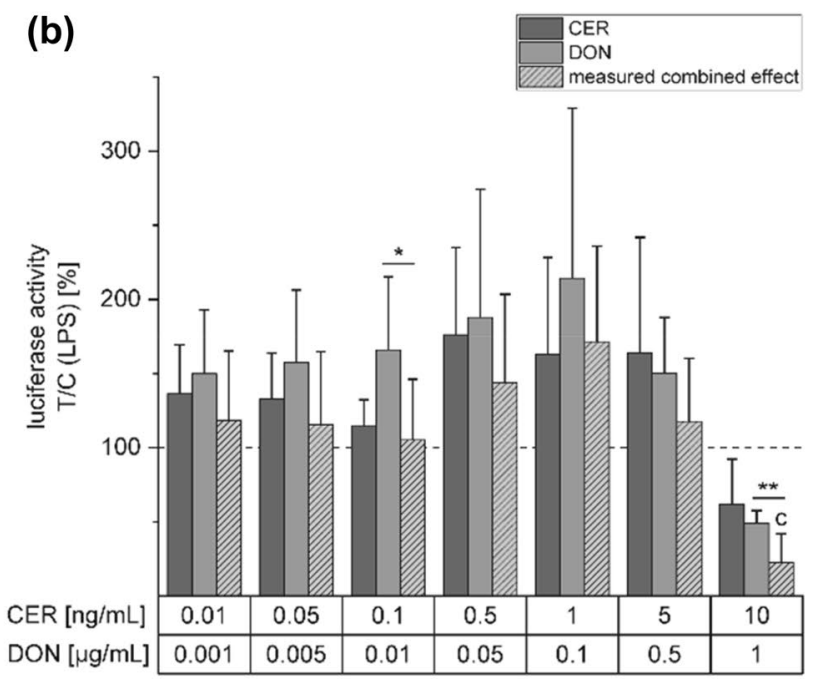

differences to the respective no-effect concentration were calculated by one-way ANOVA $(p<0.05)$ followed by Bonferroni post hoc test and are indicated as "b" (DON) and "c" (measured combined effect). Significant differences between the measured and the calculated combined effect were determined by Student's $t$ test and are indicated with “*” $(p<0.05)$ and “**” $(p<0.01)$

concentrations. Furthermore, the highest combination reduced the IL- 8 amount significantly compared to IL-1 $\beta$ treated cells. Solvent control samples ( $1 \%$ DMSO, $1 \% \mathrm{H}_{2} \mathrm{O}$ ) were below the limit of quantification and could therefore not be statistically analysed.

\section{Discussion}

Exposure to secondary fungal and bacterial metabolites might frequently occur simultaneously through our diet, not only in Africa (Abia et al. 2017) but also in Europe (Messelhausser et al. 2014). Currently, toxicity of complex toxin mixtures is an emerging field of research, but combinatory effects are often considered in only one class of contaminants, for example mycotoxins (Cano-Sancho et al. 2015; Vejdovszky et al. 2016). Hence, this study addressed the question how mixtures of bacterial toxins and mycotoxins and their potential interactions may impact on toxicological outcomes. Nonetheless, potential combinatory effects are still hard to predict and might change depending on the respective concentration range and the ratio of the components. However, identification of interactions between toxic secondary metabolites of different origins could contribute to the elucidation of potential mechanisms of action and hazard characterization.

To properly assess the risk of the substances and combinations, both hazard and exposure have to be considered. In the case of cereulide, data on both of these factors are scarce. However, Delbrassinne et al. (2012) reported the presence 
Fig. 4 Relative quantities of mRNA transcript levels of CXCL8 (a), $I L I B$ (b) and TNF (c) after $5 \mathrm{~h}$ of incubation with CER, DON and the respective combinations and $3 \mathrm{~h}$ of IL- $1 \beta$ stimulus. Relative mRNA levels were measured by qRT-PCR, calculated by the $2^{-\Delta \Delta C t}$ method (Livak and Schmittgen 2001) and related to the IL-1 $\beta$-stimulated positive control (dashed line) as fold-change. All target genes were normalised to the housekeeping genes TUBB and HPRT1. Results are presented as means + standard deviations of at least four biological replicates. Significant differences to the positive control (IL-1 $\beta$ ) were calculated by one-way ANOVA $(p<0.05)$ followed by Bonferroni post hoc test and are indicated as "a" (CER), "b" (DON) and "c" (measured combined effect). Significant differences between DON and the measured combined effect were determined by Student's $t$ test and are indicated with “*” $(p<0.05)$ and “**” $(p<0.01)$

of CER in approximately $7-13 \%$ of rice samples collected from Asian-style restaurants in Belgium. Therefore, it cannot be excluded that consumers of rice dishes are frequently exposed to CER. Consequently, it is possible that some populations of consumers have a higher burden of CER exposure. To lower the amount or avoid CER formation in foods, proper storage, especially cooling, is essential (Delbrassinne et al. 2012). Furthermore, DON is a known global food contaminant (Mishra et al. 2019) and the co-occurrence of DON and CER was recently observed in Cameroonian maize fufu (Abia et al. 2017). For evaluation of the risk assessment, further investigations are needed. To our knowledge, this is the first study focusing on the combination of a mycotoxin with a frequently co-occurring bacterial toxin.

In this study, differentiated Caco- 2 cells were used as a model of the gastrointestinal tract, as the intestine is one of the first organs that might be affected by orally ingested toxins. Applying the Neutral Red assay, we identified synergistic interactions in cytotoxicity after prolonged incubation of $48 \mathrm{~h}$ and $72 \mathrm{~h}$ with the toxin mixture of the bacterial toxin CER and the fungal toxin DON. For CER alone, the availability of cytotoxicity data in differentiated Caco-2 cells is still scarce. In differentiated and undifferentiated Caco- 2 cells, concentrations of $1 \mathrm{ng} / \mathrm{mL}$ and approximately $0.3 \mathrm{ng} / \mathrm{mL}$, respectively, reduced reported cell viabilities to $60-70 \%$ when measured in the sulforhodamine B (SRB) assay (Decleer et al. 2018; Rajkovic et al. 2014). Contrary to literature, the presented data show an enhanced cytotoxicity resulting in almost complete loss of viable cells in low concentrations of only $3 \mathrm{ng} / \mathrm{mL}$ CER after $72 \mathrm{~h}$ exposure. A possible reason for the apparent discrepancy might arise from technical issues, namely the fixation of the cells in the SRB assay by trichloroacetic acid (Skehan et al. 1990). Caco- 2 cells have been reported to possess rigid tight junctions leading to high TEER values of above $400 \Omega \times \mathrm{cm}^{2}$ (Schmutz et al. 2019). Therefore, dead cells that are still integrated in the monolayer might be measured as an artefact in total protein content. Preliminary data from our group showed that even though cells appeared to be dead in microscopic monitoring, the signal in the SRB assay reached a (a) $\operatorname{CXCL8}$

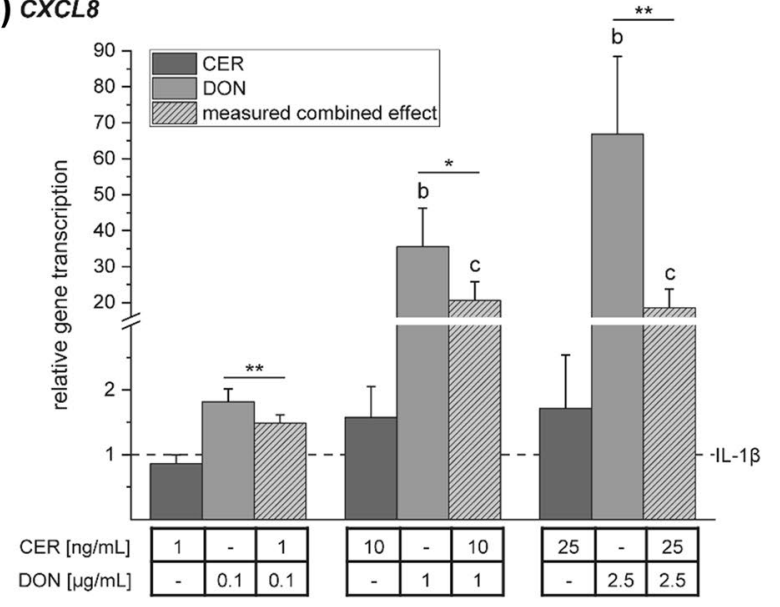

(b) $I L 1 B$

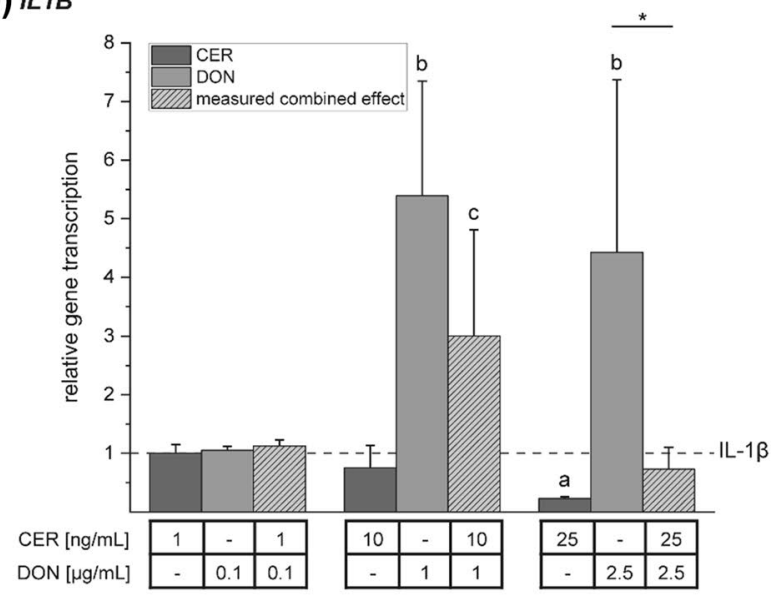

(c) TNF

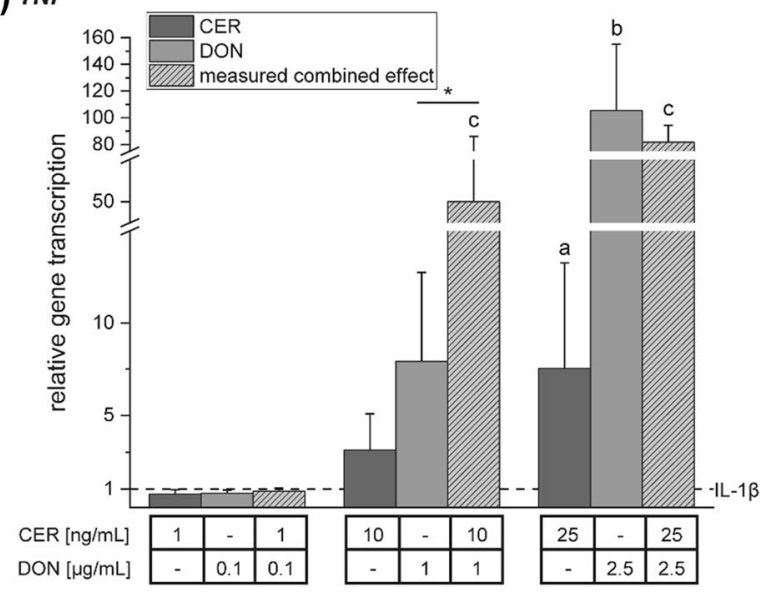

concentration-independent plateau at around $75 \%$ cell viability (data not shown). Differentiated Caco-2 cells have already been reported to be less sensitive to DON treatment than undifferentiated ones (Bony et al. 2006; Vejdovszky et al. 2016), which could also be reproduced in the presented Neutral Red assay. 


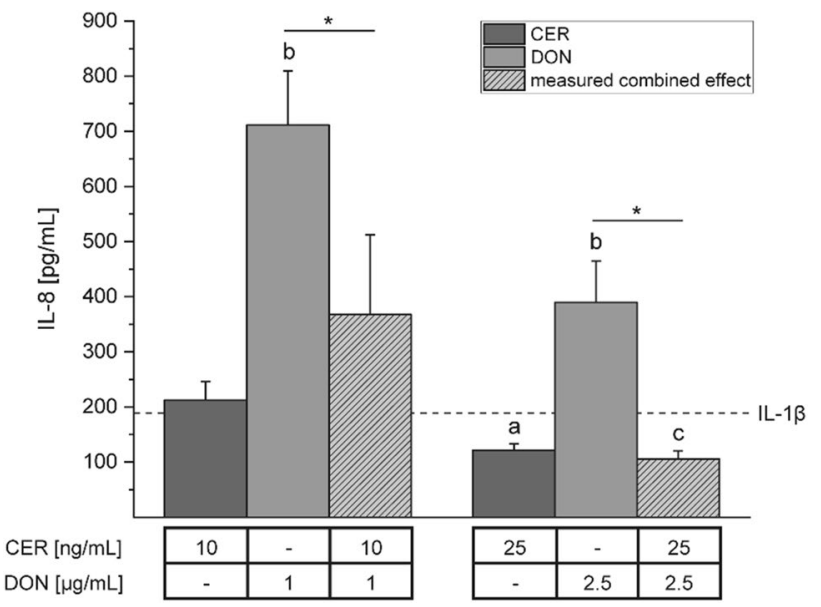

Fig. 5 Concentrations of secreted IL-8 were measured with a Human Magnetic Luminex ${ }^{\circledR}$ Assay after $5 \mathrm{~h}$ of incubation with CER, DON and the combinations thereof ( $3 \mathrm{~h}$ co-incubation with IL-1 $\beta$ ). Results are presented as means + standard deviations of three biological replicates. Significant differences to the positive control (IL-1 $\beta$ ) as well as differences between DON and the measured combined effect were calculated by Student's $t$ test and are indicated as "a" (CER), "b" $(\mathrm{DON})$ and "c" (measured combined effect) and "*" $(p<0.05)$ and “**” $(p<0.01)$, respectively

The applied toxin concentrations were chosen based on occurrence data (Abia et al. 2017; Bauer et al. 2018; Delbrassinne et al. 2012; Mishra et al. 2019; Schothorst and van Egmond 2004) and under the previously reported assumption that the substances are diluted in the intestine in $1 \mathrm{~L}$ gastric fluid and are fully bio-accessible (Ling et al. 2016; Sergent et al. 2006). Doses up to $10 \mu \mathrm{g} / \mathrm{mL}$ DON have previously been considered realistic (Van De Walle et al. 2008). Preliminary experiments were performed with the single substances to evaluate their dose-response curves. Hence, the 1:100 ratio of CER:DON was chosen for the experiments due to their similar cytotoxic potential after $24 \mathrm{~h}$ of exposure (Fig. 2b) The four chosen time points represent a broad time range justified by the colon transit time that can highly vary inter-individually between 3 and $71 \mathrm{~h}$ (Miller et al. 2017; Song et al. 2012; Southwell et al. 2009).

While after $24 \mathrm{~h}$ of incubation the CER and DON combination led to an antagonism, synergism manifests after $48 \mathrm{~h}$ and $72 \mathrm{~h}$. As DON had no effect on cell viability in the tested concentrations after 3 days, a clear synergism becomes apparent. Thus, it might be speculated that at higher concentrations the antagonistic effect of the combined toxins reverses into a synergistic interaction. Therefore, different ratios of CER and DON might be investigated in the future for better understanding of dose response and the type of interaction between substances.

First insights into the bioavailability of CER have been provided by a recent study of Bauer et al. (2018). Using a porcine model, it was shown that CER could accumulate in the gastrointestinal tract. As low amounts were found in blood and brain samples, it was suggested that CER is taken up into the body. Most strikingly, 50\% of administered CER was found in faeces and accumulated in tissue, especially the intestine reaching concentrations of $3.11 \pm 1.95 \mathrm{ng} / \mathrm{g}$ tissue in the small intestine after 7 days of exposure to $10 \mathrm{ng} /$ $\mathrm{kg}$ bodyweight (Bauer et al. 2018). These findings stress the necessity of studies on chronic low-dose effects of CER alone and in combination as the intestinal integrity might be impaired due to cytotoxic effects.

Beyond cytotoxicity, DON is well known to possess immunomodulatory properties. Therefore, our current study focused on differentially expressed and secreted proinflammatory cytokines. For this purpose, the cell model was slightly modified to imitate inflamed conditions in the intestine by applying IL- $1 \beta$ as previously described by Van De Walle et al. (2008). In this test system, the presence of CER suppressed the transcription and secretion of IL-8 compared to DON alone suggesting immunosuppressive properties after a short incubation period of only $5 \mathrm{~h}$. Furthermore, the presented results show decreased NF- $\kappa \mathrm{B}$ activation by the mixture compared to DON alone, leading to the hypothesis that CER might interfere with the NF- $\mathrm{B}$ signalling pathway. Even though, according to literature, DON may trigger or modify intestinal inflammation due to increased IL-8 secretion in Caco-2 cells (Maresca et al. 2008; Van De Walle et al. 2010a), the modification of the inflammatory response by mixtures of secondary fungal and bacterial metabolites has, to our knowledge, not been investigated yet. However, $100 \mathrm{ng} / \mathrm{mL}$ CER has been reported to partially inhibit the production of interferon- $\gamma$ in natural killer cells (Paananen et al. 2002), indicating an immunomodulatory potential.

In the present study, CER and DON show great differences in their immunomodulatory activity. The effect of CER as a single substance is dominated by the enhanced transcription of $T N F$. In the combination with DON on the other hand, CER leads to the attenuated transcription and secretion of IL-8. Even though the NF- $\kappa B$ pathway activation seems to be involved to some extent, these opposing effects cannot be fully explained thereby. Moon et al. (2007) reported on the involvement of the mitogen-activated protein kinase (MAPK) pathway, more precisely of extracellular signal-regulated kinases $1 / 2$ (ERK1/2) in the expression of IL-8 in human epithelial intestine 407 cells. By inhibition of ERK1/2, IL-8 production could be significantly reduced (Moon et al. 2007). Hence, it may be speculated that CER interferes in a similar way leading to reduced expression and secretion of IL-8. The possible involvement of reactive oxygen species (ROS), which are well known to impact the inflammatory response on several levels (Forrester Steven et al. 2018), has been monitored with the dichlorofluorescein (DCF) assay. In the present study, no significant changes 
in ROS formation could be identified (Online Resource 3). Therefore, we hypothesised that other signalling pathways are involved in the complex interplay of CER and DON. These may include the NACHT, LRR and PYD domainscontaining protein 3 (NLRP3) inflammasome, which plays a crucial role in the proteolytic processing of pro-IL-1 $\beta$ (Bauernfeind et al. 2009) or furthermore the involvement of mitophagy via the connection of NF- $\mathrm{KB}$ as a key regulator of NLRP3 (Zhong et al. 2016).

In summary, we showed that co-incubation of CER and DON can lead to different toxicological outcomes at the molecular level depending mostly on exposure time. Shortterm exposure revealed that CER reduced the pro-inflammatory potential of DON in all inflammation-related endpoints, namely NF- $\mathrm{KB}$ activation, cytokine expression and secretion. On the other hand, enhanced cytotoxicity after prolonged exposure raises the question whether the epithelial integrity of the intestine might be compromised due to combined intake of bacterial toxins and mycotoxins. Recurrent consumption of a toxin-contaminated, cereal-based diet might therefore not only facilitate inflammatory bowel diseases, but might easily culminate in severe consequences on the body, potentially promoting the progression of malnutrition and growth retardation, especially in children. Hence, further toxicological evaluation concerning potentially involved molecular mechanisms is needed to verify our hypotheses. Additionally, the occurrence of complex bacterial toxin and mycotoxin mixtures raises the question how these might interact and lead to yet unknown adverse effects.

Acknowledgements Open access funding provided by University of Vienna. The authors thank Alexander Karbalaei for contributing to the measurement of $\mathrm{NF \kappa B}$ reporter gene assays.

\section{Compliance with ethical standards}

Conflict of interest The authors declare that they have no conflict of interest.

Open Access This article is licensed under a Creative Commons Attribution 4.0 International License, which permits use, sharing, adaptation, distribution and reproduction in any medium or format, as long as you give appropriate credit to the original author(s) and the source, provide a link to the Creative Commons licence, and indicate if changes were made. The images or other third party material in this article are included in the article's Creative Commons licence, unless indicated otherwise in a credit line to the material. If material is not included in the article's Creative Commons licence and your intended use is not permitted by statutory regulation or exceeds the permitted use, you will need to obtain permission directly from the copyright holder. To view a copy of this licence, visit http://creativecommons.org/licenses/by/4.0/.

\section{References}

Abia WA, Warth B, Ezekiel CN et al (2017) Uncommon toxic microbial metabolite patterns in traditionally home-processed maize dish (fufu) consumed in rural Cameroon. Food Chem Toxicol Int J Publ Br Ind Biol Res Assoc 107(Pt A):10-19. https://doi. org/10.1016/j.fct.2017.06.011

Aichinger G, Pahlke G, Nagel LJ, Berger W, Marko D (2016) Bilberry extract, its major polyphenolic compounds, and the soy isoflavone genistein antagonize the cytostatic drug erlotinib in human epithelial cells. Food Funct 7(8):3628-3636. https://doi. org/10.1039/c6fo00570e

Aichinger G, Beisl J, Marko D (2017) Genistein and delphinidin antagonize the genotoxic effects of the mycotoxin alternariol in human colon carcinoma cells. Mol Nutr Food Research 61:2. https://doi.org/10.1002/mnfr.201600462

Aichinger G, Beisl J, Marko D (2018a) The hop polyphenols xanthohumol and 8-prenyl-naringenin antagonize the estrogenic effects of fusarium mycotoxins in human endometrial cancer cells. Front Nutr 5:85. https://doi.org/10.3389/fnut.2018.00085

Aichinger G, Puntscher H, Beisl J, Kutt ML, Warth B, Marko D (2018b) Delphinidin protects colon carcinoma cells against the genotoxic effects of the mycotoxin altertoxin II. Toxicol Lett 284:136-142. https://doi.org/10.1016/j.toxlet.2017.12.002

Bauer T, Sipos W, Stark TD et al (2018) First insights into within host translocation of the Bacillus cereus toxin cereulide using a porcine model. Front Microbiol 9:2652. https://doi.org/10.3389/ fmicb.2018.02652

Bauernfeind FG, Horvath G, Stutz A et al (2009) Cutting edge: NFkappaB activating pattern recognition and cytokine receptors license NLRP3 inflammasome activation by regulating NLRP3 expression. J Immunol (Baltimore, Md: 1950) 183(2):787-791. https://doi.org/10.4049/jimmunol.0901363

Bony S, Carcelen M, Olivier L, Devaux A (2006) Genotoxicity assessment of deoxynivalenol in the Caco- 2 cell line model using the Comet assay. Toxicol Lett 166(1):67-76. https://doi. org/10.1016/j.toxlet.2006.04.010

Campbell DI, Elia M, Lunn PG (2003) Growth faltering in rural gambian infants is associated with impaired small intestinal barrier function, leading to endotoxemia and systemic inflammation. $\mathrm{J}$ Nutr 133(5):1332-1338. https://doi.org/10.1093/jn/133.5.1332

Cano PM, Seeboth J, Meurens F et al (2013) Deoxynivalenol as a new factor in the persistence of intestinal inflammatory diseases: an emerging hypothesis through possible modulation of Th17-mediated response. PLoS ONE 8(1):e53647. https://doi. org/10.1371/journal.pone.0053647

Cano-Sancho G, Gonzalez-Arias CA, Ramos AJ, Sanchis V, Fernandez-Cruz ML (2015) Cytotoxicity of the mycotoxins deoxynivalenol and ochratoxin A on Caco-2 cell line in presence of resveratrol. Toxicol In Vitro Int J Publ Assoc BIBRA 29(7):1639-1646. https://doi.org/10.1016/j.tiv.2015.06.020

Decleer M, Jovanovic J, Vakula A et al (2018) Oxygen consumption rate analysis of mitochondrial dysfunction caused by Bacillus cereus cereulide in Caco-2 and HepG2 cells. Toxins 10:7. https ://doi.org/10.3390/toxins10070266

Delbrassinne L, Andjelkovic M, Dierick K, Denayer S, Mahillon J, Van Loco J (2012) Prevalence and levels of Bacillus cereus emetic toxin in rice dishes randomly collected from restaurants and comparison with the levels measured in a recent foodborne outbreak. Foodborne Pathog Dis 9(9):809-814. https://doi. org/10.1089/fpd.2012.1168

Ehling-Schulz M, Fricker M, Scherer S (2004) Bacillus cereus, the causative agent of an emetic type of food-borne illness. Mol Nutr Food Res 48(7):479-487. https://doi.org/10.1002/ mnfr.200400055 
Ehling-Schulz M, Svensson B, Guinebretiere MH et al (2005) Emetic toxin formation of Bacillus cereus is restricted to a single evolutionary lineage of closely related strains. Microbiology (Reading, England) 151(Pt 1):183-197. https://doi.org/10.1099/mic.0.27607 $-0$

Ehling-Schulz M, Fricker M, Grallert H, Rieck P, Wagner M, Scherer S (2006) Cereulide synthetase gene cluster from emetic Bacillus cereus: structure and location on a mega virulence plasmid related to Bacillus anthracis toxin plasmid pXO1. BMC Microbiol 6:20. https://doi.org/10.1186/1471-2180-6-20

Ehling-Schulz M, Lereclus D, Koehler TM (2019) The Bacillus cereus group: Bacillus species with pathogenic potential. Microbiol Spectr 7:3. https://doi.org/10.1128/microbiolspec

EuropeanCommission (2018) Nutrition dashboard for Cameroon. https://ec.europa.eu/europeaid/sites/devco/files/cameroon.pdf. Accessed 082018

Forrester Steven J, Kikuchi Daniel S, Hernandes Marina S, Xu Q, Griendling Kathy K (2018) Reactive oxygen species in metabolic and inflammatory signaling. Circ Res 122(6):877-902. https://doi. org/10.1161/CIRCRESAHA.117.311401

InvivoGen (2017) THP1-Lucia ${ }^{\mathrm{TM}}$ NF- $\kappa B$ cells. NF-kB Lucia ${ }^{\mathrm{TM}}$ reporter monocytes. Product information

Jaaskelainen EL, Teplova V, Andersson MA et al (2003) In vitro assay for human toxicity of cereulide, the emetic mitochondrial toxin produced by food poisoning Bacillus cereus. Toxicol In Vitro Int J Publ Assoc BIBRA 17(5-6):737-744

Kollarova J, Cenk E, Schmutz C, Marko D (2018) The mycotoxin alternariol suppresses lipopolysaccharide-induced inflammation in THP-1 derived macrophages targeting the NF-kappaB signalling pathway. Arch Toxicol 92(11):3347-3358. https://doi. org/10.1007/s00204-018-2299-4

Ling KH, Wan ML, El-Nezami H, Wang M (2016) Protective capacity of resveratrol, a natural polyphenolic compound, against deoxynivalenol-induced intestinal barrier dysfunction and bacterial translocation. Chem Res Toxicol 29(5):823-833. https://doi. org/10.1021/acs.chemrestox.6b00001

Livak KJ, Schmittgen TD (2001) Analysis of relative gene expression data using real-time quantitative PCR and the 2(-Delta Delta C(T)) method. Methods (San Diego, Calif) 25(4):402-408. https ://doi.org/10.1006/meth.2001.1262

Mahler H, Pasi A, Kramer JM et al (1997) Fulminant liver failure in association with the emetic toxin of Bacillus cereus. N Engl J Med 336(16):1142-1148. https://doi.org/10.1056/nejm199704 173361604

Maresca M, Yahi N, Younes-Sakr L, Boyron M, Caporiccio B, Fantini J (2008) Both direct and indirect effects account for the proinflammatory activity of enteropathogenic mycotoxins on the human intestinal epithelium: stimulation of interleukin- 8 secretion, potentiation of interleukin-1beta effect and increase in the transepithelial passage of commensal bacteria. Toxicol Appl Pharmacol 228(1):84-92. https://doi.org/10.1016/j.taap.2007.11.013

Messelhausser U, Frenzel E, Blochinger C, Zucker R, Kampf P, EhlingSchulz M (2014) Emetic Bacillus cereus are more volatile than thought: recent foodborne outbreaks and prevalence studies in Bavaria (2007-2013). Biomed Res Int 2014:465603. https://doi. org/10.1155/2014/465603

Mikkola R, Saris NE, Grigoriev PA, Andersson MA, SalkinojaSalonen MS (1999) Ionophoretic properties and mitochondrial effects of cereulide: the emetic toxin of B. cereus. Eur J Biochem 263(1):112-117

Miller LE, Ibarra A, Ouwehand AC (2017) Normative values for colonic transit time and patient assessment of constipation in adults with functional constipation: systematic review with metaanalysis. Clin Med Insights Gastroenterol 11:11795522177293431179552217729343. https://doi.org/10.1177/1179552217729343
Mishra S, Srivastava S, Dewangan J, Divakar A, Kumar Rath S (2019) Global occurrence of deoxynivalenol in food commodities and exposure risk assessment in humans in the last decade: a survey. Crit Rev Food Sci Nutr. https://doi.org/10.1080/10408 398.2019.1571479

Moon Y, Yang H, Lee SH (2007) Modulation of early growth response gene 1 and interleukin- 8 expression by ribotoxin deoxynivalenol (vomitoxin) via ERK1/2 in human epithelial intestine 407 cells. Biochem Biophys Res Commun 362(2):256-262. https://doi. org/10.1016/j.bbrc.2007.07.168

Naranjo M, Denayer S, Botteldoorn N et al (2011) Sudden death of a young adult associated with Bacillus cereus food poisoning. J Clin Microbiol 49(12):4379-4381. https://doi.org/10.1128/jcm.05129 $-11$

Paananen A, Mikkola R, Sareneva T et al (2002) Inhibition of human natural killer cell activity by cereulide, an emetic toxin from Bacillus cereus. Clin Exp Immunol 129(3):420-428

Pinton P, Oswald IP (2014) Effect of deoxynivalenol and other type B trichothecenes on the intestine: a review. Toxins 6(5):1615-1643. https://doi.org/10.3390/toxins6051615

Pinton P, Nougayrede JP, Del Rio JC et al (2009) The food contaminant deoxynivalenol, decreases intestinal barrier permeability and reduces claudin expression. Toxicol Appl Pharmacol 237(1):4148. https://doi.org/10.1016/j.taap.2009.03.003

Rajkovic A, Uyttendaele M, Vermeulen A et al (2008) Heat resistance of Bacillus cereus emetic toxin, cereulide. Lett Appl Microbiol 46(5):536-541. https://doi.org/10.1111/j.1472-765X.2008.02350 .X

Rajkovic A, Grootaert C, Butorac A et al (2014) Sub-emetic toxicity of Bacillus cereus toxin cereulide on cultured human enterocytelike Caco-2 cells. Toxins 6(8):2270-2290. https://doi.org/10.3390/ toxins6082270

Repetto G, del Peso A, Zurita JL (2008) Neutral red uptake assay for the estimation of cell viability/cytotoxicity. Nat Protoc 3(7):11251131. https://doi.org/10.1038/nprot.2008.75

Rouzeau-Szynalski K, Stollewerk K, Messelhäusser U, Ehling-Schulz M (2020) Why be serious about emetic Bacillus cereus: cereulide production and industrial challenges. Food Microbiol 85:103279. https://doi.org/10.1016/j.fm.2019.103279

Schmittgen TD, Livak KJ (2008) Analyzing real-time PCR data by the comparative C(T) method. Nat Protoc 3(6):1101-1108

Schmutz C, Cenk E, Marko D (2019) The alternaria mycotoxin alternariol triggers the immune response of IL-1beta-stimulated, differentiated Caco-2 cells. Mol Nutr Food Res 63(20):e1900341. https://doi.org/10.1002/mnfr.201900341

Schoeni JL, Wong AC (2005) Bacillus cereus food poisoning and its toxins. J Food Prot 68(3):636-648

Schothorst RC, van Egmond HP (2004) Report from SCOOP task 3.2.10 "collection of occurrence data of Fusarium toxins in food and assessment of dietary intake by the population of EU member states". Subtask: trichothecenes. Toxicol Lett 153(1):133-143. https://doi.org/10.1016/j.toxlet.2004.04.045

Sergent T, Parys M, Garsou S, Pussemier L, Schneider YJ, Larondelle Y (2006) Deoxynivalenol transport across human intestinal Caco-2 cells and its effects on cellular metabolism at realistic intestinal concentrations. Toxicol Lett 164(2):167-176. https:// doi.org/10.1016/j.toxlet.2005.12.006

Skehan P, Storeng R, Scudiero D et al (1990) New colorimetric cytotoxicity assay for anticancer-drug screening. J Natl Cancer Inst 82(13):1107-1112. https://doi.org/10.1093/jnci/82.13.1107

Smith LE, Stoltzfus RJ, Prendergast A (2012) Food chain mycotoxin exposure, gut health, and impaired growth: a conceptual framework. Adv Nutr (Bethesda, Md) 3(4):526-531. https://doi. org/10.3945/an.112.002188 
Song BK, Cho KO, Jo Y, Oh JW, Kim YS (2012) Colon transit time according to physical activity level in adults. J Neurogastroenterol Motil 18(1):64-69. https://doi.org/10.5056/jnm.2012.18.1.64

Southwell BR, Clarke MCC, Sutcliffe J, Hutson JM (2009) Colonic transit studies: normal values for adults and children with comparison of radiological and scintigraphic methods. Pediatr Surg Int 25(7):559-572. https://doi.org/10.1007/s00383-009-2387-x

Stewart CP, Iannotti L, Dewey KG, Michaelsen KF, Onyango AW (2013) Contextualising complementary feeding in a broader framework for stunting prevention. Matern Child Nutr 9(Suppl 2):27-45. https://doi.org/10.1111/mcn.12088

Ueno Y (1977) Mode of action of trichothecenes. Ann Nutr Aliment 31(4-6):885-900

Van De Walle J, Romier B, Larondelle Y, Schneider YJ (2008) Influence of deoxynivalenol on NF-kappaB activation and IL-8 secretion in human intestinal Caco-2 cells. Toxicol Lett 177(3):205214. https://doi.org/10.1016/j.toxlet.2008.01.018

Van De Walle J, During A, Piront N, Toussaint O, Schneider YJ, Larondelle Y (2010a) Physio-pathological parameters affect the activation of inflammatory pathways by deoxynivalenol in Caco- 2 cells. Toxicol In Vitro Int J Publ Assoc BIBRA 24(7):1890-1898. https ://doi.org/10.1016/j.tiv.2010.07.008

Van De Walle J, Hendrickx A, Romier B, Larondelle Y, Schneider YJ (2010b) Inflammatory parameters in Caco-2 cells: effect of stimuli nature, concentration, combination and cell differentiation. Toxicol In Vitro Int J Publ Assoc BIBRA 24(5):1441-1449. https ://doi.org/10.1016/j.tiv.2010.04.002
Vangoitsenhoven R, Rondas D, Crevecoeur I et al (2014) Foodborne cereulide causes beta-cell dysfunction and apoptosis. PLoS ONE 9(8):e104866. https://doi.org/10.1371/journal.pone.0104866

Vejdovszky K, Warth B, Sulyok M, Marko D (2016) Non-synergistic cytotoxic effects of Fusarium and Alternaria toxin combinations in Caco-2 cells. Toxicol Lett 241:1-8. https://doi.org/10.1016/j. toxlet.2015.10.024

Webb J (1963) Effect of more than one inhibitor, vol 1. Academic Press, New York, pp 66-79

Zhong Z, Umemura A, Sanchez-Lopez E et al (2016) NF-kappaB restricts inflammasome activation via elimination of damaged mitochondria. Cell 164(5):896-910. https://doi.org/10.1016/j. cell.2015.12.057

Publisher's Note Springer Nature remains neutral with regard to jurisdictional claims in published maps and institutional affiliations. 